\title{
Diversity of Weed Flora, Weed Density and Crop Weed Competition in Maize
}

\author{
A. Subba Ramireddy*, A. S. Rao, G. Subba Rao, T .C. M Naidu, \\ A. Lalitha Kumari and N. Trimurthulu
}

\author{
Regional Agricultural Research Station, Angrau, Guntur, Andhra Pradesh, India \\ *Corresponding author
}

\section{Keywords}

Maize, Weeds, Diversity of Weed

Flora, Crop Weed

Competition

Article Info

Accepted:

15 December 2019

Available Online:

20 January 2020

A B S T R A C T

Maize (zea mays 1.) Is one of the most important crops among the cereals in the world agricultural economy both as food and fodder crop and is regarded as "queen of cereals". Weeds can suppress crop growth and yield by effectively competing with crop for environmental resources like water, light, nutrients and production of allelopathic compounds. The weed flora differs widely with environment and soil conditions. Generally, weeds are found in larger numbers and with more vigour, because of their wider adaptability even under extremities of climatic, edaphic and biotic stresses. High persistence nature of weeds is attributed to their ability of high seed production and seed viability. Determination of the most critical period of crop-weed competition for nutrients, moisture, light and space is of greater importance to make weed management practices more effective and economical and thereby increasing crop yield.

\section{Introduction}

In Andhra Pradesh, rabi maize followed by greengram crop sequence is promising for reaping high returns by farmers but many reasons are responsible for the lower yields of maize. Among the several factors, the most dominant factor responsible for the lower yields of maize are weeds, which competes with crop for nutrients, water, sunlight and space.
Wide spacing, intensive use of inputs and initial slow growth of maize are some of the factors responsible for increased weed growth. Weeds can suppress crop growth and yield by effectively competing with crop for environmental resources like water, light, nutrients and production of allelopathic compounds. The extent of reduction in grain yield of maize has been reported to be in the range of 33 to 50 per cent depending on type of weed species in standing crop (Hawaldar 
and Agasimani, 2012). At the earlier times, since no synthetic chemicals were known, weed control was achieved by some methods such as hand weeding, crop rotation, polyculture and other management practices that were low input but sustainable.

With the discovery of synthetic herbicides in the early 1930s, there was a shift in control methods towards high input and targetoriented ones. Now labour component in agriculture is becoming scarce, not available at time and cost prohibitive. Use of herbicides to manage weeds forms an excellent alternative to manual weeding. In India, till date only pre-emergence application of atrazine pendimethalin has been widely recommended for the control of weeds in maize.

There is a need of post-emergence herbicide usage for management of weeds which occur at 15-25 days of crop and offer severe competition for growth resources, thereby lowering the productivity of maize. Hence, it is proposed to test the new post emergence herbicides without residual effect in maize has greater field applicability. Effective fertilizer management is also an important component of integrated weed management systems (Blackshaw et al., 2007).

\section{Weed Flora}

The weed flora differs widely with environment and soil conditions. Generally, weeds are found in larger numbers and with more vigour, because of their wider adaptability even under extremities of climatic, edaphic and biotic stresses. High persistence nature of weeds is attributed to their ability of high seed production and seed viability. Kamble et al. (2005) reported that the major weed flora in maize field comprised of the broad leaf weeds viz., Digera arvensis, Celosia argentea, Euphorbia hirta, Lagasca mollis, Parthenium hysterophorus and the narrow leaf grassy weeds viz., Cynodon dactylon and Dinebra arabica. Silvernail (2005) from Serbia (Europe) stated that in organically produced sweet maize the most dominant weeds were Digitaria sanguinalis, Setaria faberi, Amaranthus hybridus, Panicum miliaceum and Ambrosia trifida. Chalka and Nepalia (2005) from Udaipur, Rajasthan noticed that maize was infested with a mixed flora of weeds, chiefly consisting of Echinochloa crusgalli, Echinochloa colonum, Portulaca oleracea, Commelina benghalensis, Digera arvensis, Trianthema portulacastrum and Phyllanthus niruri. Sharma and Gautam (2006) from Pantnagar (Uttarakhand) reported that Cynodon dactylon, Cyperus rotundus, Echinochloa colonum, Echinochloa crusgalli, Agropyron repens, Parthenium hysterophorus, Digitaria sanguinalis, Eclipta alba, Euphorbia hirta and Commelina benghalensis were dominant weeds in maize.

In an experiment conducted at Annamalai University (Tamil Nadu) Selvakumar and Sundari (2006) observed that Trianthema portulacastrum, Cyperus rotundus, Cynodon dactylon and Phyllanthus niruri were predominant weeds in maize. Malviya and Singh (2007) from Faizabad, Uttar Pradesh noticed that maize was infested with a mixed flora of weeds chiefly consisting of Cyperus rotundus, Cynodon dactylon, Eclipta alba, Solanum nigrum, Digera arvensis, Phyllanthus niruri, Echinochloa colonum and Commelina benghalensis.

The weed flora consisting of Cynodon dactylon, Cyperus rotundus, Trianthema portulacastrum, Phyllanthus niruri, Digera arvensis, Euphorbia hirta, Aristolochia bracteata, Commelina benghalensis, Sida acuta and Cleome viscosa were dominant in maize on clay loam soils of Bapatla (Vanaja, 2007). Muhammad et al. (2007) observed that the major weeds in fodder maize field at 
Peshawar (Pakistan) were Cyperus rotundus, Cynodon dactylon, Chenopodium album, Echinochloa crusgalli and Cucumis prophetarum. Kumar (2008) indicated that the common weed species noticed in clay loam soils of Agricultural Research Station, Devihosur, Haveri district (Karnataka) during kharif,2007 were Cynodon dactylon, Digitaria marginata, Dinebra retroflexa, Echinochloa colonum, Eleusine indica, Panicum spp.and Setaria italica among monocots; Ageratum conyzoides, Amaranthus viridis, Acanthospermum hispidum, Alternanthera sessilis, Argemone mexicana, Commelina benghalensis, Cyanotis cucullata, Corchorus trilocularis, Digera arvensis, Desmodium diffusum, Euphorbia hirta, Euphorbia prostrata, Euphorbia geniculata, Lagasca mollis, Leucas aspera, Malvastrum coromandelianum, Oldenlandia diffusa, Phyllanthus niruri, Portulaca oleracea, Parthenium hysterophorus, Physalis minima and Tridax procumbens among dicots and Cyperus rotundus among sedges.

Chopra and Angiras (2008) from Palampur (Himachal Pradesh) reported that Digitaria sanguinalis, Echinochloa colonum, Panicum dichotomiflorum, Commelina benghalensis, Cyperus iria, Brachiaria ramosa, Cynodon dactylon and Ipomoea purpurea were dominant weeds in maize. Singh et al. (2009) declared that the major predominant weed species infesting rainfed maize in medium to deep black soils at Bijapur (Karnataka) were Cyperus rotundus, Cynodon dactylon, Eclipta alba, Solanum nigrum, Digera arvensis, Phyllanthus niruri, Echinochloa colonum and Commelina benghalensis.Mahadevaiah et al. (2010) from Tirupati (Andhra Pradesh) observed that Cynodon dactylon, Digitaria sanguinalis and Dactyloctenium aegyptium among grasses, Cyperus rotundus among sedges, Commelina benghalensis and Trichodesma indicum among broad leaved weeds as dominant weeds in baby corn.
In a study conducted by Srividya et al. (2011) reported that weed species namely Cyperus rotundus, Phyllanthus niruri, Digera arvensis and Cynodon dactylon were dominant in maize at Agricultural College, Bapatla. The weeds such as Cynodon dactylon, Digitaria sanguinalis and Panicum repens among grasses, sedges like Cyperus iria and Cyperus rotundus, broadleaved weeds like Cleome viscosa, Borreria hispida, Amaranthus spinosus and Trianthema portulacastrum were dominant in sweet corn in Tirupati (Sunitha et al. 2010).

The weeds such as Digitaria sanguinalis and Dactyloctenium aegyptium among grasses, sedge like Cyperus rotundus, broad leaved weeds like Cleome viscosa, Borreria hispida, Celosia argentea, Merremia aegyptia and Trichodesma indicum were dominant in sweet corn in Tirupati (Sandhya Rani et al.2011). The experimental field of maize in infested with Echinochloa crusgalli and Cynodon dactylon among monocots; Cyperus rotundus among sedges; and Amaranthus viridis, Digera arvensis, Portulaca oleracea, Alternanthera sessilis and Trianthema spp., among dicots (Arvadiya et al. 2012).

Ahmed and Susheela (2012) indicated that the major weed flora associated with maize crop in the sandy loam soils in college farm, Rajendranagar, Hyderabad during kharif, 2010 consisted of three monocots viz., Cynodon dactylon, Digitaria sanguinalis, Dactyloctenium aegyptium and eight dicots viz., Parthenium hysterophorus, Commelina benghalensis, Amaranthus viridis, Euphorbia geniculata, Celosia argentea, Digera arvensis, Trichodesma indicum and Lagasca mollis.

Ishrat et al. (2012) reported that the weed flora of the experimental site comprised of grasses, sedges and broad leaved weeds in maize. The important grassy weeds observed were Cynodon dactylon, Dinebra retroflexa, 
Echinochloa colonum and Eleusine indica. Cyperus rotundus was alone in sedge category. Among the broad leaved weeds, Parthenium hysterophorus, Commelina benghalensis, Portulaca oleracea, Cyanotis cucullata, Phyllantus niruri and Amaranthus viridis were the dominant weeds.Muhammad et al. (2012) stated that the weed species infesting autumn planted maize field in Faisalabad was Trianthema portulacastrum, Cyperus rotundus, Coronopus didymus, Cynodon dactylon and Convolvulus arvensis. Aleem et al. (2012) conducted a field experiment at College of Agriculture, Rajendranagar, Hyderabad on sandy loam soils and reported that the major weed flora associated with maize crop in the experimental site consisted of four monocots viz., Cyperus rotundus, Cynodon dactylon, Digitaria sanguinalis,Dactyloctenium aegyptium and eight dicots viz., Parthenium hysterophorus,Commelina benghalensis, Amaranthus viridis, Euphorbia geniculata, Celosia argentea, Digera arvensis, Trichodesma indicum and Lagasca mollis.

The weed flora consisting of Cynodon dactylon, Echinochloa crusgalli, Cyperus rotundus, Trianthema portulacastrum, Phyllanthus niruri, Digera arvensis, Physalis minima, Euphorbia hirta, Aristolochia bracteata, Meremia everta, Commelina benghalensis, Sida acuta and Cleome viscosa were dominant in maize on clay loam soils of Bapatla (Praveena, 2013).

In a study conducted by Rama Devi (2013) weed species such as Cyperus rotundus among sedges, Trianthema portulacastrum, Cleome viscosa, Euphorbia hirta, Phyllanthus niruri and Digera arvensis among the dicots and Cynodon dactylon among grasses were reported in baby corn on sandy clay loam soils of Bapatla. Sakthivel et al. (2014) noticed Trianthema portulacastrum, Digera arvensis, Cleome gynandra, Parthenium hysterophorus,
Datura metal, Dactyloctenium aegyptium, Setaria verticillata and Cyperus rotundus were the major weed species in maize on sandy loam soils of Tamil Nadu Agricultural University, Coimbatore.

Madhavi et al. (2014) observed that the experimental field comprised of Cyperus rotundus among sedges, Digitaria spp, Dactyloctenium aegyptium, Dinebra arabica, Cynodon dactylon and Eleusine indica among grasses, Parthenium hysterophorus, Melilotus alba, Trianthema portulacastrum, Euphorbia geniculata, Commelina spp, Tridax procumbens and Amaranthus viridis among broad leaved weeds in maize crop.

Anil kumar et al. (2015) indicated that the most important weeds that can be associated with maize/maize-based cropping systems in the country are Echinochloa colonum, Brachiaria ramosa, Digitaria sanguinalis, Dactyloctenium aegyptium, Eleusine indica, Setaria glauca, Sorghum halepense, Panicum spp. Cynodon dactylon, Digitaria setigera, Digitaria ciliaris, and Leptochloa chinensis among grasses; Ageratum conyzoides ,Galinsoga parvifjora, CommeIina benghalensis, Undernia cilata, Polygonum hydropiper, Euphorbia geniculata, Oxalis latifolia, Celosia argentea, Cleome viscose, Sida acuta, Aschynomene indica, Acanthospermum hispidum, Portulaca oleracea, Phyllanthus niruri, Amaranthus viridis, Acalypha indica, Tridax procumbens, Ipomoea pestigridis, Parthenium hysterophorus and Euphorbia hirta among non-grassy weeds and Cyperus rotundus and Cyperus iria among sedges.

Mukherjee and Rai (2015) reported that major weed flora were Polygonum persicaria, $P$. pensylvanicum, $P$. orientale, Oldenlandia diffusa, Oldenlandia aquatica, Oxalis corniculata, Stellaria media, Stellaria aquatic, Physalis minima, Solanum nigrum, Hydrocotyl 
ranunculoides, Ageratum conyzoides (appeared at latter part of crop growth), the sedge like Cyperus rotundus and the grasses like Cynodon dactylon, Digitaria ciliaris, Setaria glauca, Echinochloa spp. in maize.

Singh et al. (2015) recorded dominant weeds in the maize field were Medicago denticulata, Avena ludoviciana, Phalaris minor and Chenopodium album. Barad et al. (2016) revealed that the weed flora in the experimental site at Junagadh constituted by monocot weeds viz., Brachiaria spp. (17.67\%), Asphodelus tenuifolius L. Cav. (1.79\%), Indigofera glandulosa L. (1.40\%), Echinochloa colona L. (1.23\%)and Dactyloctenium aegyptium Beauv (4.79\%), dicotweeds viz., Digera arvensis Forsk (19.21\%), Amaranthus viridis L. (2.28\%), Physalis minima L(2.77\%), Launaea nudicaulis L. (1.79\%), Euphorbiahirta L. (7.77\%), Chenopodium album L. (19.70\%), Portulaca oleracea L. (3.52\%) and Phyllanthus niruri $(2.02 \%)$ and sedge weed Cyperus rotundus L. (21.29\%).

\section{Critical Period of Crop-Weed Competition}

Determination of the most critical period of crop-weed competition for nutrients, moisture, light and space is of greater importance to make weed management practices more effective and economical and thereby increasing crop yield. Nayital et al. (1989) observed that critical period of crop weed competition in maize was from 20-60 DAS on sandy loamy soils of Bajuara (Kullu). The critical period of competition by weeds coincided with early stages of the crop i.e. 15 to 45 DAS on clay loam soils of Tamil Nadu (Tyagi et al. 1993; Suresh Kumar and Sundari, 2002). The weedy environment beyond 30 days and up to 45days after sowing was detrimental to maize growth and causes yield loss (Porwal, 2000).Ghanizadeh et al. (2009) from Sushtar, Iran stated that critical period for weed control in maize was from 5-9 leaf stage (17-36 DAS). Anil kumar et al. (2015) reported that the emergence of maize and weeds was simultaneous and the first 20-60 days was the most critical period of competition for the crop. However, in winter maize the period beyond 30 days and up to 45 days after sowing was detrimental to maize growth. Experiments conducted at various locations indicated that the most critical period of crop weed competition in maize ranged from 3to 6 weeks after sowing (Varshney, 1990; Sharma and Nayital, 1993; Shad et al. 1993; Ghosheh et al. 1996; Dogan et al. 2004; Nagalakshmi et al. 2006 and Barad et al. 2016).

\section{Yield Losses}

In situations ideal or otherwise for crop and weed growth, weeds always thrive well. Increase in weed population has a direct effect on reduction in crop yield. The reduction of corn yield by weed competition has been reported by many workers. Season long infestation of composite weed flora in maize field reduced the grain yield by $28-100 \%$ (Angiras and Singh, 1989 and Pandey et al.2001) at various maize growing locations Palampur and Almora, respectively. Presence of Amaranthus retroflexus in corn field reduced maize grain yield by 7,20 and 32 per cent in the presence of 5, 10, and 20 weed plants per $\mathrm{m}^{-2}$ (Rola and Rola, 1992).

Sharma and Nayital (1993) found that yield loss in maize due to unchecked weed growth was $61.3 \%$ as compared to weed free check on sandy loam soils of Bajaura (Kullu). Santos et al. (1993), reported that in silty clay loam texture soils at Sonning (UK), maize grain yield loss ranged from 40 to 80 per cent if weeds were uncontrolled. According to Vargessel et al. (1994) the weed distribution in the corn field was not a critical consideration in determining yield loss. Maize 
grown in the presence of weeds viz. Amaranthus palmeri, Eriagrostis diffusa, Bidens odorata, Brassica campestris for the whole cycle of the crop showed an 86 to 90 per cent reduction in grain yield (Amador, 1995).

Ferro et al. (1996) opined that depression effect of weeds on grain yield of maize was strongly related with weed dry weight and weed cover, respectively.Virendar (1997) observed that weeds found a serious negative factor in crop production and resulted loss in crop yield by 10 to 15 per cent or more. More over germination and vigour of maize seeds decreased with an increase in weed density (Saayman et al. 1997). Sen et al. (2000) reported that, due to weed competition, yield losses occur up to 15 to 75 per cent in maize crop. The loss in grain yield due to unchecked weed growth was to the extent of 32.4 to 42.3 per cent (Sharma et al. 2000) at PAU, Ludhiana.

Pandey et al. (2002) reported that grassy weeds offered maximum competition to crop reducing grain yield by 77.4 per cent followed by non-grassy weeds of about 44.2 per cent and sedges 38.4 per cent. In an experiment conducted by Walia et al. (2005) at Punjab Agricultural University, Ludhiana the yield loss recorded due to unchecked weed growth was up to $56 \%$ in rainfed maize on sandy loam soils.

Maize being a rainy season and widely spaced crop gets infested with variety of weeds and subjected to heavy weed competition, which often inflicts huge losses ranging from 28 to 100 per cent in maize (Patel et al., 2006a).

Malviya and Singh (2007) reported that season long weed competition reduced the grain yield of maize by $70.24 \%$ compared with the weed free conditions on salty loams of Uttar Pradesh and also stated that $41 \%$ yield loss due to unchecked weed growth in zero tillage maize on clay loam soils. In an experiment conducted at Tirupati, Sunitha et al. (2010) observed that yield loss due to uncontrolled weed growth in sweet corn was to an extent of $40-42 \%$ on sandy loam soils. Patil et al. (2014) at TCA farm, Dholi, found that yield loss due to unchecked weed growth was up to $58 \%$ in rabi maize.

Anil kumar et al. (2015) revealed that In India, presence of weeds reduced the maize yields by $27-60 \%$, depending upon the growth and persistence of weed population.

\section{Weed Density and Dry Weight}

Pre-emergence application of atrazine @ 0.5 $\mathrm{kg}$ a.i ha ${ }^{-1}$ followed by intercultivation at 35 DAS resulted in the lowest weed dry weight on clay loam soils of Udaipur (Mundra et al., 2002). Anil Kumar and Thakur (2004) from Himachal Pradesh recorded the lowest weed dry weight accumulation with pre-emergence application of alachlor @ $1.5 \mathrm{~kg}$ a.i ha ${ }^{-1}$ supplemented with hand weeding at 20 DAS than with application of herbicide alone. Preemergence application of atrazine @ $0.5 \mathrm{~kg} \mathrm{a.i}$ $\mathrm{ha}^{-1}$ followed by one hoeing at 20 DAS resulted in the lowest weed dry weight on clay loam soils of Yavatmal in kharif maize (Kamble et al.2005).

Tripathi et al. (2005) reported that atrazine @ $0.5 \mathrm{~kg}$ a.i ha ${ }^{-1}$ could provide effective control of weeds when it was supplemented with one hand weeding at 20 DAS in maize on sandy loam soils at Kanpur. Nagalakshmi et al. (2006) obtained the lowest weed density and dry matter with two hand weedings at 21 and 42 DAS in maize on clay loam soils at Agricultural college, Bapatla. Patel et al. (2006a) from Anand (Gujarat) reported the lowest weed density and dry matter with hand weeding at 20 and 40 DAS on sandy loam soils. 
Hussein et al. (2008) observed that plant spacing affected dry weight of weeds growing with maize. Biomass of weed species was decreased, in most cases, under narrow plant spacing. Weeds were controlled by all treatments compared with the nontreated check; however, herbicide treatments were not superior to hand hoeing treatments. Application of the three weed control treatments resulted in less weed biomass and greater maize yield in narrow- compared to wide-spacing maize.

According to Demjanova et al. (2009) only 2.6 perennial weed plants per quadrant in conventional tillage as compared to 7.5-9.0 in reduced tillage treatments were noted. Tillage system was more influential than crop rotations on the weed density and diversity and weed biomass. Srividya et al. (2011) stated that application of either atrazine @ $1.25 \mathrm{~kg}$ a.i ha ${ }^{-1}$ or pendimethalin @ $1.5 \mathrm{~kg}$ a.i $\mathrm{ha}^{-1}$ in combination with directed spray of paraquat@ $0.6 \mathrm{~kg} \mathrm{a.i} \mathrm{ha}{ }^{-1}$ in between rows at 3 WAS recorded significantly lower weed density and dry matter comparable with that of two hand weedings and intercultivation with power weeder at 4 WAS on clay loam soils of Bapatla.

Pre-emergence application of atrazine @ 1.0 $\mathrm{kg}$ a.i $\mathrm{ha}^{-1}$ followed by hand weeding at 40 DAS resulted in the lowest weed dry weight in sweet corn on heavy black soils of Navasari Agricultural University, Navasari (Arvadiya et al., 2012).

Sandhya Rani and Karuna Sagar (2013) reported the lowest weed density and dry weight with two hand weedings at 20 and 40 DAS in maize on sandy loam soils at Tirupati.

At crop research centre, RAU (Pusa) Ranjana Kumari et al. (2014) recorded the lowest weed density and dry weight accumulation with preemergence application of atrazine @
$1.0 \mathrm{~kg}$ a.i ha ${ }^{-1}$ followed by working with power weeder at 45 DAS in summer maize.

Amandeep et al. (2014) noticed significantly lower weed dry matter with pre-emergence tank mix application of atrazine $0.75 \mathrm{~kg}$ a.i $\mathrm{ha}^{-1}+$ pendimethalin $0.75 \mathrm{~kg}$ a.i $\mathrm{ha}^{-1}$ at University Seed Farm, Nabha (Punjab). Deshmukh et al. (2014) observed that atrazine @ $1.0 \mathrm{~kg}$ a.i ha ${ }^{-1}$ followed by mechanical or hand weeding at 30 DAS proved better in controlling weed density and dry matter in kharif maize at Punjabrao Deshmukh Krishi Vidyapeeth, Akola. In another experiment pre-emergence application of atrazine @ 0.75 kg a.i ha ${ }^{-1}$ followed by 2, 4-D @ 0.5 kg a.i ha ${ }^{1}$ recorded the lowest weed density and it was on par with hand weeding at 20 and 40 DAS in maize on clay soils at Akola, Maharashtra (Sonawane et al.2014).

Sanjay kumar patel et al. (2015) evaluated productivity of kharif maize (Zea mays L.) under legumes intercropping system and its effect on weeds. Intercropping of maize with cowpea, soybean, blackgram or greengram, effectively reduced the population and dry weight of weeds as compared to sole crop of maize.

All legumes intercropping in maize significantly increased maize equivalent yield as compared to sole maize. Metolachlor was found significantly reducing weed population and dry weight which was statistically at par with hand weeding and alachlor and gave the significantly the highest maize equivalent yield.

\section{References}

Ahmed, A. M. A and Susheela, R. 2012. Weed management studies in kharif maize. The Journal of Research ANGRAU. 40 (3): 121-123. 
Aleem, Ahmed, M.A and Susheela, R. 2012. Weed management studies in kharif maize. The Journal of Research, ANGRAU. 40 (3):124-128.

Amandeep Singh Sindhu, Jaswinder Singh, Sat Pal Saini and Vinay Kumar. 2014. Chemical control of hardy weeds in kharif maize at farmers' fields in Punjab. In Proceedings of Biennial Conference of Indian Society of Weed Science on "Emerging Challenges in Weed Management" February 15-17, 2014. Directorate of Weed Science Research, Jabalpur, Madhya Pradesh, India. P-260.

Angiras, N.N and Singh, C.M. 1989. Economic analysis of integrated weeds management in maize. Indian Journal of Weed Science. 21(1): 29-36.

Anil Kumar, B and Thakur, K.S. 2004. Effect of integrated nutrient management on promoting composite maize varieties under rainfed mid hill conditions of Himachal Pradesh. Indian Journal of Agricultural Sciences. 74 (1): 40-42.

Anil Kumar, Jai Kumar, R., Puniya Amit Mahajan., Neetu Sharma and Lobzang Stanzen. 2015. Weed management in maize-based cropping system. Indian Journal of Weed Science 47(3): 254 266.

Arvadiya, L. K., Raj, V. C., Patel, T. U and Arvadia, M. K. 2012.Influence of plant population and weed management on weed flora and productivity of sweet corn (Zea mays). Indian Journal of Agronomy. 57(2):162-167.

Barad, B., Madhukia, R.K., Gohil,B.S and Chhodavadia, S.K. 2016. Integrated weed management in rabi popcorn maize (Zea mays var. everta). Journal of Crop and Weed, 12(1):150-153

Blackshaw, R.E., Anderson, R. L and Lemerle, D. 2007. Cultural Weed Management: Principles, Concepts and
Technology. Oxford Ford Shire, UK.3537.

Chalka, M. K and Nepalia, V. 2005. Production potential and economics of maize (Zea mays) intercropped with legumes as influenced by weed control. Indian Journal of Agronomy. 50 (2): 119-122.

Chopra, P and Angiras, N. N. 2008. Influence of tillage and weed control methods on weeds, yield and yield attributes of maize (Zea mays L.). Indian Journal of Weed Science.40 (1 \& 2): 47-50.

Demjanova, E., Macak, M., Caloviu, I., Majernik, F., Stefan Tyr and Jozef Smatana. 2009. Effects of tillage systems and crop rotation on weed density weed species composition and weed biomass in maize. Agronomy Research. 7(2): 785-792.

Deshmukh, J.P., Singrup, P., Dandge, M.S., Bhale, V.M and Paslawar, A.N. 2014. Integrated weed management in maize. In Proceedings of Biennial Conference of Indian Society of Weed Science on "Emerging Challenges in Weed Management" February 15-17, 2014. Directorate of Weed Science Research, Jabalpur, Madhya Pradesh, India. P-33.

Dogan, M.N., Unay, A., Boz, $\mathrm{O}$ and Albay, F.2004. Determination of optimum weed control timing in maize. Turkish Journal of Agriculture. 28 (1\&2): 349354.

Ferro, A., Scanzio, M., Acerti, S.M., Brow, H and Cussane, W. 1996. Critical period of weed interference in maize. InProceedings of the Second International Weed Control Congress. Copenbayen, Denmark.171-176.

Ghanizadeh, H., Lorzadeh, S and Ariannia, N. 2009. Critical period for weed control in corn in the south-west of Iran. Asian Journal of Agricultural Research. 20(1): 1-7. 
Ghosheh, H. Z., Holshouser and Chandler, J. M. 1996. The critical period of Johnson grass (Sorghum halepense) control in field corn (Zea mays). Weed Science.44 (4): 944-947

Hawaldar Shantveerayya and Agasimani, C. A. 2012. Effect of herbicides on weed control and productivity of maize (Zea mays L.). Karnataka Journal of Agricultural Sciences. 25 (1): 137-139.

Hussein, F., Abouzeina, I.M., El-Metwally and Desoki, E.R. 2008. Effect of weed control treatments on maize yield and associated weeds in sandy soils. American Eurasian Journal of Agricultural and Environmental Sciences.4 (1): 9-17.

Ishrat, D. H., Hunashal, C. S., Malligwad, L. H., Basavaraj, B and Chimmad, V. P. 2012. Effect of pre and post emergence herbicides on weed control in maize (Zea mays. L.). Karnataka Journal of Agricultural Sciences. 25 (3):392-394.

Kamble, T. C., Kakade, S. U., Nemade, S. U., Pawar, R. V and Apotikar, V. A. 2005. Anintegrated weed management in hybrid maize. Crop Research. 29(3):396-400.

Kumar, R. T. 2008. Evaluation of different herbicides and method of application on maize (Zea mays L.) under northern transition zone of Karnataka. M.Sc. (Agri.) Thesis. University of Agricultural Science, Dharwad, India.

Madhavi, M., Ramprakash, T., Srinivas, A and Yakadri, M. 2014. Topramezone $(33.6 \% \mathrm{SC})+$ atrazine (50\% WP) tank mix efficacy on maize. Biennial Conference of Indian Society of Weed Science on "Emerging Challenges in Weed Management" February 15-17, 2014. Directorate of Weed Science Research, Jabalpur, Madhya Pradesh, India.

Mahadevaiah, K., KarunaSagar, G and Sumathi, V. 2010. Influence of integrated weed management practices on weed dynamics and yield of baby corn in Southern agro-climatic zone of Andhra Pradesh. Indian Journal of Weed Science. 42 (3\&4): 238-240.

Malviya, A and Singh, B. 2007. Weed dynamics, productivity and economics of maize (Zea mays) as affected by integrated weed management under rainfed condition. Indian Journal of Agronomy. 52 (4): 321-324

Muhammad, R., Muhammad, J. and Tahira, Z. M. 2007. Yield and yield components of maize as affected by various weed control methods under rainfed conditions of Pakistan. International Journal of Agriculture and Biology.9(1):152-155.

Muhammad, A. N., Muhammmad, A., Asghar, A., Muhammad, $\mathrm{T}$ and Muhammad, A. 2012. Effect of weed control practices on weeds and yield of autumn planted maize (Zea mays L.). National seminar on Role of agronomy in national food security. 67-72.

Mukherjee, P. K and Rai, A. 2015. Weed management in no-tilled dibbling maize within rice residue. 25th Asian-Pacific Weed Science Society Conference on "Weed Science for Sustainable Agriculture, Environment and Biodiversity", 13-16 October, 2015. Hyderabad, India.

Mundra, S.L., Vyas, A.K and Mailwal, P.L. 2002. Effect of weed and nutrient management on nutrient uptake by maize and weeds. Indian Journal of Agronomy. 43 (3): 378-383.

Nagalakshmi, K.V.V., Chandrasekhar and Subbaiah, G. 2006. Weed management for efficient use of nitrogen in rabi maize. The Andhra Agricultural Journal. 53(1\&2): 14-16.

Nayital, S.C., Sharma, J.A and Singh, C.M. 1989. Weed crop competition studies in maize under Kulu valley conditions. 
Indian Journal of Weed Science. 21(1): 47-50.

Pandey, A. K., Ved, P and Gupta. 2002. Effect of integrated weed management practices on yield and economics of baby corn (Zea mays). Indian Journal of Weed Science. 72(4):206-209.

Pandey, A. K., Prakash, V., Singh, P., Prakash, K., Singh, R.D and Mani, V. P. 2001. Integrated weed management in maize. Indian Journal of Agronomy. 46(2): 260-265.

Patel, G. N., Patel, G. J., Goyal, S. N and Patel, B. G. 2000. Integrated weed management in rabi maize. Gujarat Agricultural University Research Journal. 25(2):88-90.

Patil, S., Kumar, M.S and Singh, D. 2014. Efficacy of the herbicides and their combination on nut grass dominated rabi maize. In Proceedings of Biennial Conference of Indian Society of Weed Science on "Emerging Challenges in Weed Management" February 15-17, 2014. Directorate of Weed Science Research, Jabalpur, Madhya Pradesh, India. P-264.

Porwal, M.K. 2000. Economics of weed control measures in winter maize ( $\mathrm{Zea}$ mays). Indian Journal of Agronomy. 45(2): 344-347.

Praveena, S. 2013. Effect of tillage and weed management on nitrogen use efficiency of maize. M.Sc (Ag) Thesis. Acharya N.G. Ranga Agricultural University, Hyderabad. India.

Rama Devi, B. 2013. Performance of baby corn as influenced by nitrogen levels and weed control practices. M.Sc $(A g)$ Thesis. Acharya N.G. Ranga Agricultural University, Hyderabad, India.

Ranjana Kumari, D.K., Roy, $\mathrm{M}$ and Dharminder. 2014. Integrated weed management in summer maizeIn Proceedings of Biennial Conference of
Indian Society of Weed Science on "Emerging Challenges in Weed Management" February 15-17, 2014. Directorate of Weed Science Research, Jabalpur, Madhya Pradesh, India. P207.

Rola, H and Rola, J. 1992. Effect of competition from Amaranthus retrofluexus $\mathrm{L}$. on sugarbeet and maize crop and possibilities for its chemical control in Southwest Poland. InProceedings of $16^{\text {th }}$ German Conf. on Weed Biology and Control.10-12 March, 1992.Germany.215-220.

Sakthivel, N., Revathi, M and Bhuvana Devi, S. 2014. Effect of the tillage and weed management in maize and sunflower cropping system. In Proceedings of Biennial Conference of Indian Society of Weed Science on "Emerging Challenges in Weed Management" February 15-17, 2014. Directorate of Weed Science Research, Jabalpur, Madhya Pradesh, India. P-153.

Sandhya Rani, B., KarunaSagar, G and Maheswara Reddy, P. 2011. Effect of the integrated weed management with low volume herbicides in sweet corn. Indian Journal of Weed Science. 43 (1\&2): 110-112.

Sandhya Rani, B and Karuna Sagar, G. 2013. Effect of integrated weed management on growth, yield and economics of sweet corn. Agricultural Science Digest. 33 (1): 52-55.

Sanjay Kumar Patel, Shishir Kumar and Mohd. Kaleem. 2015. Studies of the weed control on maize under legumes based intercropping system. Research in Environmental and Life Sciences. 8(1): 81-82.

Santos, D.M.D., Drennan, D.S.H and Fround Williams, R.J. 1993. Effect of time of weed removal on transplanted and direct seeded maize. In: Brighton crop 
protection conference weeds. Proc. an International Conf. Brighton, UK.

Selvakumar, T and Sundari, A. 2006. Effect of intercropping systems and weed management practices on weeds in maize (Zea mays). Indian Journal of Weed Science. 38 (1\&2): 133-134.

Sen, A., Singh, S. C., Sharma, S. N., Singh, A. K., Singh, R and Pal, A. K. 2000. Agronomy of maize inbred parental line. Indian Farming. 1: 18-20.

Shad, R. A. Chatha, M. Q and Nawaz, H. 1993. Weed management studies in maize. Pakistan Journal of Agricultural research. 14(1):44-50.

Sharma, J and Nayital, S.C. 1993. Weed management in maize (Zea mays. L) + black gram intercropping in mid-hills of sub-humid zone of Himachal Pradesh. Indian Journal of Weed Science. 25 (1\&2): 43-46.

Sharma, C.K and Gautam, R.C. 2006. Effect of tillage, seed rate and weed control methods on weeds and maize. Indian Journal of Weed Science. 38 (1\&2): 5861.

Sharma, A. R., Toor, A.S and Sur, H. S.2000. Effect of intercultural operations and scheduling of atrazine application on weed control and the productivity of rainfed maize (Zea mays L.) in Shiwalik foot hills of Punjab. Indian Journal of Agricultural Science. 70(11): 757-761.

Silvernail, A. 2005. Weed management in the organic sweet corn. Horticultural Sciences. 40 (4): 1071-1072.

Singh, H and Singh, S. 2009. Weed management and soil micro-organisms studies in irrigated summer groundnut (Arachis hypogaea L.). Karnataka Journal of Agricultural Sciences.. 41 (1 \& 2): 103-107.

Singh, R., Dubey, R.P., Singh, V.P., Ghosh, D., Srarthmbal, C., Barman K. K and Choudhury, P.P. 2015. Impact of tillage, residue and weed management on growth and yield of maize. $25^{\text {th }}$ Asian-Pacific Weed Science Society Conference on "Weed Science for Sustainable Agriculture, Environment and Biodiversity", Hyderabad, India during 13-16 October, 2015

Sonawane, R.K., Dandge, M.S., Kambel, A.S and Shingrup, P.V. 2014. Effect of herbicides on nutrient uptake by weeds, crops and yield of kharif maize. In Proceedings of Biennial Conference of Indian Society of Weed Science on "Emerging Challenges in Weed Management” February 15-17, 2014. Directorate of Weed Science Research, Jabalpur, Madhya Pradesh, India. P-47.

Srividya, S., Chandrasekhar, $\mathrm{K}$ and Veeraghavaiah, R. 2011. Effect of tillage and herbicide use on weed management in maize. The Andhra Agricultural Journal. 58 (2): 123-126.

Sunitha, N., Maheswara Reddy, P and Malleswari Sadhineni. 2010. Effect of cultural manipulation \& weed management practices on weed dynamics \& performance of sweet corn. Indian Journal of Weed Science. 42 (3\&4): 184-188.

Suresh Kumar, S.M and Sundari, A. 2002. Studies on the effect of major nutrients and crop-weed competition period in maize. Indian Journal of Weed Science. 34 (3\&4): 309-310.

Tripathi, A.K., Tewari, A.N and Prasad, A. 2005. An integrated weed management in rainy season maize (Zea mays L.) in Central Uttar Pradesh. Indian Journal of Weed Science.37(3\&4): 269- 270.

Tyagi, R.C., Tyagi, A.K., Karwasra, R.S and Singh, B.R. 1993. Crop weed competition in maize. In Integrated Weed Management for Sustainable Agriculture. Proc. of an Indian Soc. of Weed Sci. International Symp. Hisar, India.18-20. 
Vanaja, C.H. 2007. Weed management studies in kharif maize. M.Sc. (Ag) Thesis. Acharya N.G. Ranga Agricultural University, Hyderabad, India.

Varshney, J.G. 1990. Efficacy of atrazine with adjuvants on weed suppression in maize in mid hills of Meghalaya. Indian Journal of Weed Science. 22(1\&2): 2731.
Virendar, S. 1997. Herbicides for effective weed control. Pestology.21: 2.

Walia, U.S., Brar, L.S and Singh, B. 2005. Recommendations for the weed control in field crops. Research Bulletin, Department of Agronomy, Agro meteorology and Forestry, PAU, Ludhiana.

\section{How to cite this article:}

Subba Ramireddy. A, A. S. Rao, G. Subba Rao, T .C. M Naidu, A. Lalitha Kumari and Trimurthulu. N 2020. Diversity of Weed Flora, Weed Density and Crop Weed Competition in Maize. Int.J.Curr.Microbiol.App.Sci.9(01):1001-1011.

doi: https://doi.org/10.20546/ijcmas.2020.901.113 